\title{
Implementation of CPPB-IRT, WISE, and Halal Guarantee System on Bread Production
}

\author{
Bambang Suhardi *, Nabilla Indah Putri, Rahmaniyah Dwi Astuti \\ Department of Industrial Engineering, Sebelas Maret University, Surakarta, Indonesia \\ Jl. Ir. Sutami No.36A Kota Surakarta,Telp. (0271) 632110 \\ *Corresponding author: bambangsuhardi@staff.uns.ac.id
}

\section{ARTICLE INFO}

Article history

Received September 30, 2018

Revised February 9, 2019

Accepted February 11, 2019

Available Online February 14, 2019

Keywords

CPPB-IRT

Good Manufacturing Process

WISE

Halal Guarantee System

SOP

\section{ABSTRACT}

Bread is food that many consumed in Indonesia. It usually consumed and a substitute for rice. PT. $\mathrm{X}$ is an Indonesian company that produces dry bread and wet bread. The company must implement a Good Manufacturing Process (GMP) and Halal Guarantee System (HGS) to ensure the food safety that the company produced. The company is also obliged to pay attention to Occupational Safety and Health in the work environment by applying WISE. This study consists of five staged. The stages include identification of the condition of the company, CPPB inspection, WISE examination, HGS inspection, and proposed improvements in the production process. The results of the study show some elements that have not been fulfilled. These elements include 6 CPPB elements, 9 WISE elements, and 8 HGS elements. The results of the study also provided several studies. Some of the recipients were improvements in the Standart Operational Procedure (SOP) for the receipt and receipt of materials, and the SOP for the receipt and receipt of industrial non-processed materials.

\section{This is an open-access article under the CC-BY-SA license.}

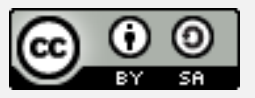

\section{Introduction}

The food industry in Surakarta City has a significant role in the economy. The number of food industries is 20 units $(15.87 \%)$ of all industrial sector. This industry has a workforce of 1,014 people $(8.14 \%)$ of the total workforce working in the industrial sector [1]. To improve the competitiveness of the food industry, employers must implement food safety and Occupational Safety and Health (OSH). Food safety needs to be considered by consumers. Consumers avoid things that are harmful when consuming food products [28]. OSH needs to be considered to prevent work accidents [8, 9]. In addition to paying attention to food safety and OSH, the food industry also consider halal factors. Halal food is not only consumed by Muslim consumers but also consumed by non-Islamic consumers. The concept of halal is not only concerned with aspects of religion but cleanliness and health $[10,11]$. Therefore, the state should provide protection and guarantees to the public regarding product halalness $[12,13]$. 
Food safety, halal guarantee, and Occupational Safety and Health (OSH) in Small Medium Enterprise (SME) are interest to study. Research on the procedure of food products for home industries has been carried out by several researchers. In Indonesia, this problem is abbreviated CPPB-IRT. Some previous research has conducted by Sonaru, et al. [2], Wijayant and Laeliocattleya [3] also Herlambang, et al. [4]. Their aims of the study are to achieve is to analyze the incompatibility of CPPB-IRT requirements in the production process in the SME. Some researchers attempt to identify potential hazards in the work environment as a basis for making work improvements. That research has conducted by Made [8], Suhardi, et al. [9], Rahayu, et al. [14], Rohmawan and Restuputri [15], and Islami [16]. The difference in research conducted by these researchers is on methods for identifying potential hazards. Moreover, Moreover, the investigation of halal product issues have been carried out by Backhouse and Mohamad [17] and Ma'rifat and Sari [18]. The purpose of the study was to find out the application of the halal guarantee system in the food industry. Putri, et al. [19] and Septina, et al. [20] have conducted research that combined more than one method. They combined the CPPB-IRT approach and halal certificate on SME food. Damarasri [21] dan Suhardi, et al. [16] attempt to combine the CPPB method and Work Improvement in Small Enterprise (WISE).

One of the food industries in Surakarta City is the bakery. Generally, there are many differences in the production floor with CPPB standards and the implementation of OSH. These incompatibilities include 1) dusty walls in the production room, 2) no chimneys to air circulation, and 3) workers in the production do not use personal protective equipment. This condition causes food to be contaminated. To expand its product marketing, companies must implement food safety standards. Furthermore, companies must attend to $\mathrm{OSH}$ issues on production. Moreover, companies must pay attention to halal products. Halal labels on packaging increase Indonesian people's trust. Halal certificates are needed to differentiate halal products from non-halal products [17].

Several studies have been conducted before by researchers. However, the difference in this research with previous research is about the use of methods and scope of discussion. This study attempts to combine three methods such: CPPB, OSH, and halal guarantee. No previous research has combined these three methods. The purpose of this study is to propose improvements in bread making based on $\mathrm{CPPB}, \mathrm{OSH}$, and halal guarantee certificates (HGS).

\section{M ethods}

\subsection{Research framework}

The research framework for improving the production process is shown in Fig. 1. Some of these stages were described included 1) Study of literature; 2) Evaluate nonconformities using CPPB, WISE, and HGS; 3) Summarizes the results of nonconformities based on CPPB, WISE, and HGS; 4) The selection of improvement priorities with the Delphi method, and 5) Proposed improvements.

\subsubsection{Study of literature}

This stage was done to obtain the literature to solve the problem. The literature used includes books and journals related to CPPB, OSH, and HGS. This CPPB was based on guidelines issued by The National Agency of Drug and Food Control of the Republic of Indonesia (BPOM). OSH Literature used the Work Improvement in Small Enterprise 
(WISE) guide. Moreover, HGS was based on a guide from the Council of Ulama Republic of Indonesia (LP-POM MUI).

\subsubsection{Evaluate nonconformities using CPPB, WISE, and HGS}

The CPPB evaluation procedure was carried out by interviews and direct observation in the company. In this investigation, there were 14 criteria evaluated [2-7]. A portion of the CPPB checklist is shown in Table 1.

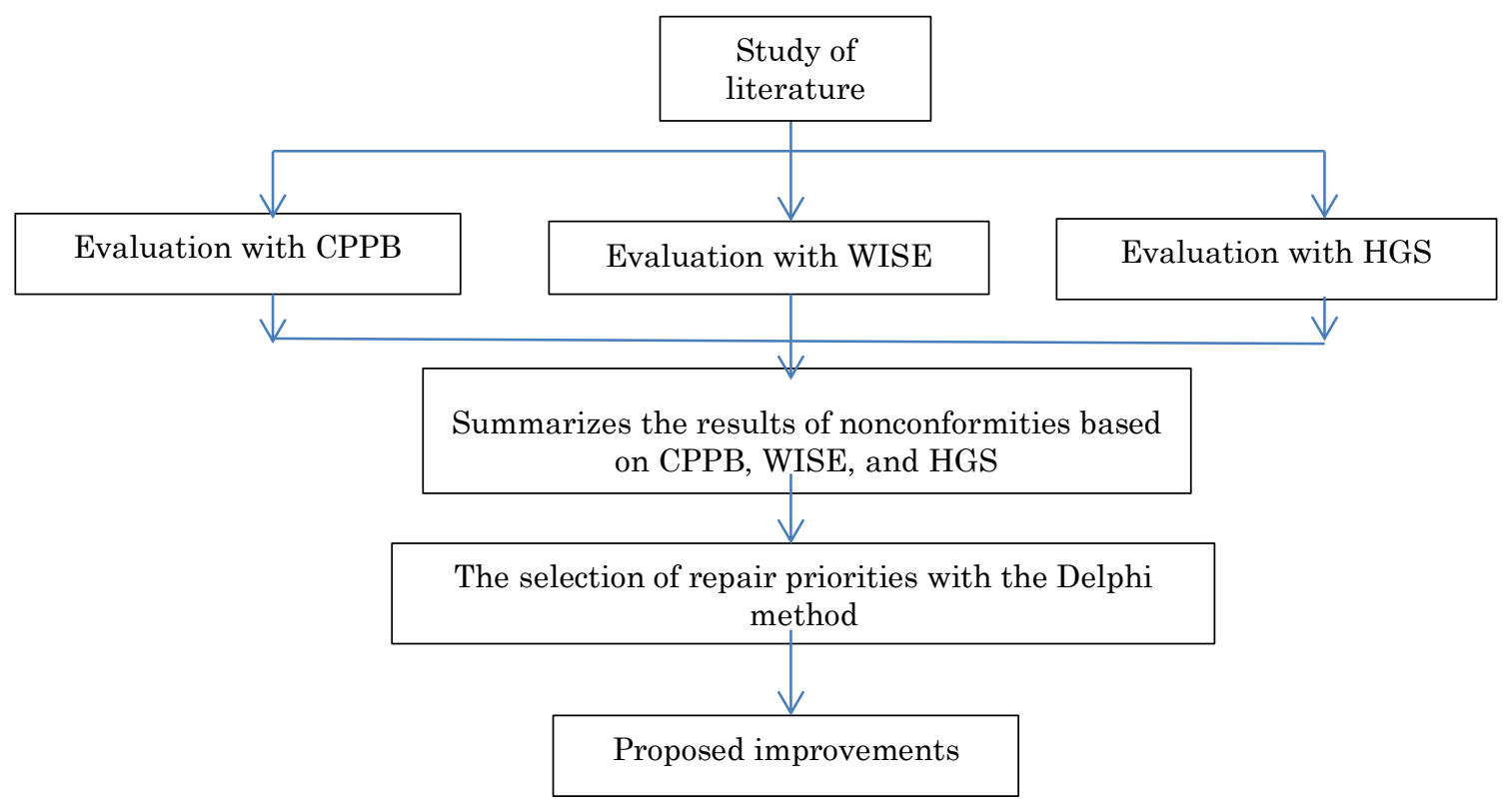

Fig. 1. Research Framework

Table 1. Checklist of CPPB

\begin{tabular}{|c|c|c|c|c|c|c|}
\hline \multirow{2}{*}{ No } & \multirow{2}{*}{ Elements Checked } & \multirow{2}{*}{ Current Condition } & \multicolumn{4}{|c|}{ Mismatch } \\
\hline & & & MI & MA & $\mathrm{SE}$ & CR \\
\hline A & $\begin{array}{l}\text { Location and Production } \\
\text { Environment }\end{array}$ & & & & & \\
\hline 1 & $\begin{array}{l}\text { The location and environment } \\
\text { are not maintained, dirty, and }\end{array}$ & $\begin{array}{l}\text { Well maintained corporate } \\
\text { environment }\end{array}$ & & & & \\
\hline & dusty & There is no rubbish pile & & & & \\
\hline & & The trash can is closed & & & & \\
\hline B & Building and Facility & & & & & \\
\hline 2 & $\begin{array}{l}\text { The production area is narrow, } \\
\text { difficult to clean, and is used to } \\
\text { produce products other than food }\end{array}$ & & & & & \\
\hline
\end{tabular}

We attempt to assess the bakery company based on the CPPB checklist. We wrote the current conditions in the bakery company based on the elements examined. If it finds a discrepancy, we gave a $\sqrt{ }$ sign in the mismatching column. There are four discrepancies included minor (MI), major (MA), serious (SE) and critical (CR). In minor nonconformities, if the MI is not fulfilled, it gives potential influence on product quality. In major nonconformities, if this is not met, it affects the efficiency of product safety control. In 
Serious non-compliance, if not fulfilled, it affects product safety. If Critical mismatch not met, it has an impact on product safety directly. The critical mismatch is a requirement that must be fulfilled.

There are eight aspects evaluated by using the WISE checklist [16, 21]. A portion of the WISE checklist is shown in Fig. 2. Evaluation procedures used the WISE checklist are as follows: (1) Determine the work area examined, (2) Take a few minutes to go around and observe around the work area, (3) For each action, mark 'No' or 'Yes.' If the response has been applied, put a 'No.' If you propose an action, give a sign 'Yes.' (4) Determine some urgent actions, and put a 'Priority' sign for the response. (5) Write suggestions for corrective actions in the 'Description' section. At HGS, there are 11 criteria evaluated using the HGS checklist [12, 18-20]. A portion of the HAS checklist is shown in Table 2.

Have clear and marked transportation routes.

Do you propose action?

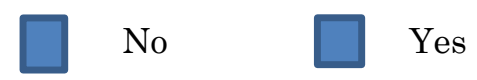

Priority

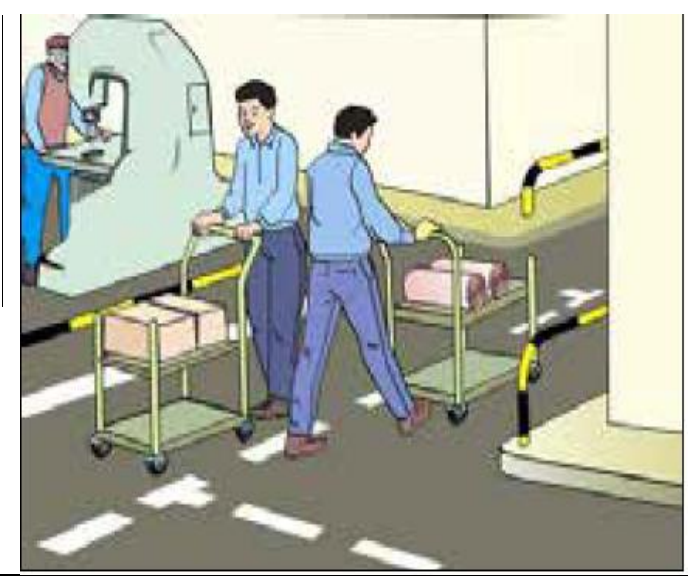

Information:

Fig. 2. Checklist WISE

Table 2. Checklist of HGS

\begin{tabular}{lllll}
\hline No & \multicolumn{1}{c}{ Questions } & Result & Explanation \\
\hline $1 \quad$ Halal Policy & $\begin{array}{c}\text { Yes } \\
(\sqrt{ })\end{array}$ & $\begin{array}{c}\text { No } \\
(\sqrt{ })\end{array}$ & $\begin{array}{c}\text { NA } \\
(\sqrt{ })\end{array}$ & \\
\hline 1. & Has the halal policy been & & & \\
& established? & & \\
2. & $\begin{array}{l}\text { Has the halal policy been } \\
\text { disseminated/disseminated to all } \\
\text { stakeholders (top management, } \\
\text { halal management team, workers, } \\
\text { production facilities, suppliers) }\end{array}$ & & \\
\hline
\end{tabular}

The HGS evaluation procedure is carried out by interviews and direct observation. In the check column, there are multiple choices such as 'YES,' 'NO,' and 'NA.' NA describe Not Applicated by company.

\subsubsection{Summarizes the results of nonconformities based on CPPB, WISE, and HGS}

The next stage is to summarize all findings of discrepancies obtained from CPPB, WISE, and HGS. Unsuitable results are as material for the improvement of the company. 


\subsubsection{The selection of improvement priorities with the Delphi method}

The choice of improvement priorities is made using the Delphi method. Delphi is a method based on harmonizes the communication process of a group to get solutions [22]. Hsu and Sandford [22] claimed that the Delphi was carried out in 4 rounds. 1) exploration of opinion. We questioned experts regarding the problems. Questions conducted verbally. Experts were asked to answer questions. All information was collected from experts. Round 2) summarizes the opinions of experts and communicate it. We summarized all opinions and communicated to all Company experts. Every company expert finds out other expert opinions. Every expert has the freedom to maintain or change his opinion based on the views of other experts. Round 3) looking for information on the reasons for experts related to the opinions. Revision of opinion stage two gives two possible results opinions such as convergent or divergent. If there are opinions that are different from other opinions, We are looking for information about the reasons for it. Round 4) evaluation. The process is carried out to produce an appropriate opinion.

\subsubsection{Proposed improvements}

The results of the Delphi method became a reference in the process of improving bread at the Company.

\subsection{Data collection and analysis}

Data collections were done in the company PT. X. It is an Indonesian company that produces dry bread and wet bread. There are 37 elements examined based on the CPPB checklist. The WISE list consists of 58 items that must be examined. There are 11 criteria for the HGS considered. The respondents were used in the Delphi method are six experts.

\section{Results and Discussion}

The results of the identification of nonconformities use the CPPB, WISE, and HGS checklist are included in the following sections:

\subsection{CPPB Checklist Check in the Company}

The evaluation results show six elements that have not met the standard. The six items are divided into 5 Serious categories and 1 Critical category. Serious non-compliance includes a) 2 aspects of building criteria and facilities, b) 1 element of employee health and hygiene criteria, c) 1 element of maintenance criteria and hygiene and sanitation program, d) 1 aspect of process control criteria. Critical Non-compliance is a food label elements. Nonconformity Based on CPPB Standards shown in Table 3.

\subsection{Examination of the WISE Checklist}

The results of the identification showed nine elements did not meet the standard. Nonconformity Based on WISE Standards be seen in Table 4. 


\subsection{Inspection Checklist HGS}

Based on the results of the identification of the Company's HGS checklist, eight elements have not met the standard. Aspects of non-conformity based on the HGS standard can be seen in Table 5 .

Table 3. Nonconformity Based on CPPB Standards

\begin{tabular}{|c|c|c|c|}
\hline No & Elements Checked & Current Condition & Impact \\
\hline 1 & $\begin{array}{lr}\text { Floors, walls, and } \\
\text { ceilings } & \text { not } \\
\text { maintained, } & \text { dirty, } \\
\text { dusty and slimy } & \end{array}$ & $\begin{array}{l}\text { Dirty floor, The walls, and ceiling } \\
\text { are dusty, and there are } \\
\text { spiderwebs }\end{array}$ & $\begin{array}{l}\text { The production room } \\
\text { unclean and has the } \\
\text { potential to cause } \\
\text { pollution to the food } \\
\text { produced }\end{array}$ \\
\hline 2 & $\begin{array}{l}\text { Ventilation, doors, and } \\
\text { windows are not } \\
\text { maintained, dirty, and } \\
\text { dusty. }\end{array}$ & $\begin{array}{l}\text { The door is not equipped with } \\
\text { gauze. There are open vents } \\
\text { equipped with gauze, but the vents } \\
\text { are dirty and dusty. There is no } \\
\text { window in the production room }\end{array}$ & $\begin{array}{l}\text { The production room } \\
\text { unclean and has the } \\
\text { potential to cause } \\
\text { pollution to the food } \\
\text { produced. }\end{array}$ \\
\hline 3 & $\begin{array}{l}\text { Employees in the food } \\
\text { production department } \\
\text { do not wear fatigues } \\
\text { and wear jewelry. }\end{array}$ & $\begin{array}{l}\text { Employees use fatigues, hats, } \\
\text { aprons, use footwear but do not use } \\
\text { gloves and masks. }\end{array}$ & $\begin{array}{l}\text { Potential to cause } \\
\text { contamination of food } \\
\text { produced from the } \\
\text { hands of workers }\end{array}$ \\
\hline 4 & $\begin{array}{l}\text { Waste in the } \\
\text { environment and the } \\
\text { production room is not } \\
\text { immediately discarded. }\end{array}$ & $\begin{array}{l}\text { Trash cans are covered. However, } \\
\text { garbage is disposed of to polling } \\
\text { stations when the trash bag is full. }\end{array}$ & $\begin{array}{l}\text { this is lead to } \\
\text { contamination of the } \\
\text { food produced and } \\
\text { cause unpleasant } \\
\text { odors in the } \\
\text { production floor }\end{array}$ \\
\hline 5 & $\begin{array}{l}\text { The industry does not } \\
\text { have or does not follow } \\
\text { the flow chart of food } \\
\text { production }\end{array}$ & $\begin{array}{l}\text { There is no flow chart for setting a } \\
\text { standard production procedure. } \\
\text { Only regular notes }\end{array}$ & $\begin{array}{l}\text { The industry does not } \\
\text { have methods that be } \\
\text { used to monitor } \\
\text { production carried } \\
\text { out. }\end{array}$ \\
\hline 6 & $\begin{array}{l}\text { Food label does not list } \\
\text { product name, list of } \\
\text { ingredients used, net } \\
\text { weight/contents, name } \\
\text { and address of } \\
\text { Industry, expiration } \\
\text { date, production code, } \\
\text { and registration } \\
\text { number of product }\end{array}$ & $\begin{array}{l}\text { The food label does not include the } \\
\text { production code. The Company only } \\
\text { knows the production code }\end{array}$ & $\begin{array}{l}\text { Consumers cannot } \\
\text { see the production } \\
\text { date of the product }\end{array}$ \\
\hline
\end{tabular}

Explanation :

No. $1-5$ is a serious category mismatch

No. 6 is a critical category mismatch 
Table 4. Nonconformity Based on WISE Standards

\begin{tabular}{|c|c|c|}
\hline No & Element checked & Current Condition \\
\hline 1 & $\begin{array}{l}\text { Provides ramps rather } \\
\text { than making stairs at } \\
\text { work }\end{array}$ & $\begin{array}{l}\text { There are stairs to connect } \\
\text { the } 1 \text { st floor to the } 2 \text { nd floor. } \\
\text { Moreover, there are two } \\
\text { steps from the production } \\
\text { floor to the packaging place }\end{array}$ \\
\hline 2 & $\begin{array}{l}\text { Use a train, trolley, or } \\
\text { another device that } \\
\text { uses wheels when } \\
\text { moving materials. }\end{array}$ & $\begin{array}{l}\text { Workers manually transfer } \\
\text { bread from the production } \\
\text { room (carrying containers } \\
\text { using hands). Some workers } \\
\text { use both sides to give } \\
\text { containers. }\end{array}$ \\
\hline
\end{tabular}

$3 \quad$ Using a protective and permanent barrier to prevent direct contact with moving machine parts

4 Check, clean and maintain machines, including electrical cables regularly

5 Move heat, noise, dust, and chemical sources from a common work area.

\begin{tabular}{|c|c|}
\hline 6 & $\begin{array}{l}\text { Place separate waste } \\
\text { containers in the } \\
\text { workplace for various } \\
\text { types of waste }\end{array}$ \\
\hline 7 & $\begin{array}{l}\text { Ensure that } \\
\text { installations, } \\
\text { equipment, and } \\
\text { equipment are } \\
\text { maintained regularly } \\
\text { and repairs are carried } \\
\text { out by competent } \\
\text { technicians }\end{array}$ \\
\hline 8 & Ensure safe \\
\hline
\end{tabular}

9 Establish an OSH policy and provide adequate safety and health training for all workers
In the bread dough grinder, there are rotating and not closed parts

The company has

technicians to maintain the electrical installations used. However, checks are not carried out regularly

For heat from the oven, it has been moved using a chimney that is directly connected from the oven. However, for the smoke produced from the process of roasting glutinous rice, there is not yet

Disposal of waste or garbage into one place. Trash is not separated by category.
Checks are not conducted regularly

$12 \mathrm{~kg}$ of liquid petroleum gas storage is placed in an open room

At present, the industry does not yet have an OSH policy for workers and the industry has also not provided training on $\mathrm{OSH}$ for all workers
Impact
Workers can fall if they do not pay attention to the steps. Especially when workers are carrying bread containers.

Workers feel tired quickly because they have to go back and forth from the production room to the packaging room. especially in the production line, there are stairs from the production room to the packaging

Potential to endanger the safety of workers while doing dough grinding

Potentially endangering the safety of workers and can harm Ganep's bread. Because if there is damage to the engine can inhibit the production process.

The smoke produced from the roasting process has the potential to cause contamination of the food produced.

Causes breeding grounds for organisms that can cause disease and cause unpleasant odors in the production room

Potentially endangering the safety of workers and can harm Ganep's bread. Because if there is damage to the engine can inhibit the production process

\section{Potential for fire}

Potential to cause an unsafe and uncomfortable work environment and can increase workplace accidents 
Table 5. Nonconformity Based on HGS Standards

No Elemen Checked

1 Have written Do not have written procedures procedures for conducting training for all personnel involved in critical activities

2 Have a written procedure for inspecting incoming goods

3 Has a procedure for the production section

Do not have a written system for the inspection of incoming goods. Workers only check the physical condition of the goods received. Moreover, no one has been given the responsibility to inspect the goods coming.

Does not have written procedures for the production section. Roti Ganep only provides information on how production activities are carried out.

\begin{tabular}{ll}
\hline Have written \\
procedures for \\
washing \\
production \\
facilities
\end{tabular}

5 Have written procedures for storing materials and products including storage in warehouses

6 Have written Do not have written procedures procedures to regarding the traceability of guarantee the certified products derived from traceability of materials that meet the criteria certified products

7 Have written Do not have written procedures procedures for regarding the implementation of conducting internal audits

8 Save evidence of the implementation of management reviews have been provided.

Do not have written procedures for storing materials and products. internal audits.

Does not maintain evidence of the application of management reviews that have been carried out
Impact

Company employees, not all understand their responsibilities in the implementation and continuous improvement of the halal guarantee system.

If there is damage to the goods or goods received that are not by the order, workers who inspect goods at that time are confused when having to request replacement goods to the supplier.

There are no proper procedures that can be used as guidelines by workers in carrying out production activities. If an error occurs in the production made, it confuses when it comes to tracing the error.

The company cannot guarantee that the cleanliness and safety of the production equipment used is guaranteed to be clean and secure in accordance with existing standards.

The company cannot guarantee that the cleanliness and safety of the materials stored are guaranteed to be clean and secure. In addition, it has the potential to confuse workers when they want to find or collect materials from the warehouse. Because there are no procedures that can be used as guidelines

The company cannot ensure that every material used has met the requirements.

The company does not conduct periodic internal audits.

Does not have official evidence if the Company has conducted a management review of the effectiveness of the implementation of HGS and improvements that must be made in the future. 


\subsection{Implementation and Results of the Delphi Method}

The Delphi method is used to find priority improvements based on the results of CPPB, WISE, and HGS mismatches that have been done. The Delphi method process is carried out in 4 rounds.

In Round 1, we give open questions about the implementation of CPPB, WISE, and HGS in the Company. The results of the respondents' answers regarding the application of CPPB, WISE, and HGS in the Company have been well implemented. However, deficiencies must be corrected at the Company. Improvements fixed by the respondent are administrative improvements. The admin improvement is the creation of a Standard Operating Procedure (SOP). In addition, from the results of examinations using the HAS checklist, many SOP documents have not been approved by the Company.

In Round 2, We described the SOP that the Company had not owned. It is being adapted with the Company's HGS non-conformity. Based on the search results, the proposed improvements lead to administrative improvements such as the fulfillment of SOPs that have not been met. Furthermore, the Company needs to shorten SOP documents that it does not yet have. SOPs that are not yet owned are SOPs for washing production facilities, SOPs for checking and receiving raw materials, SOPs for halal production, SOPs for traceability, and internal audit SOPs. After the description was carried out, respondents were allowed to provide opinions on each SOP that the Company did not yet have.

Round 3 selects SOPs from 5 SOPs that have not been received by the Company. At this stage, each respondent gives an opinion about the SOP made. Respondent A agreed to make SOPs for receiving and receiving materials. Responding B approved the making of halal production SOPs and facility washing SOPs. Respondent C agreed to the making of facilities washing SOPs and SOPs for receiving and receiving materials. Respond D approves SOP for inspection and receipt of materials. The SOP is divided into two, namely checking and receiving industrial processed raw materials and industrial non-processed materials.

Round 4 is to choose an SOP that is a priority for improvement. Based on the previous stage, there were 3 SOP proposals. The SOP includes washing up production facilities, checking and receiving raw materials for industrial and non-processed industrial processes, and a halal production. The three proposed SOPs was chosen as a priority for improvement. Based on the results of the question and answer, the Company needs to make an SOP for the inspection and receipt of raw materials for industrial and nonprocessed industrial products. The SOP for check and receipt of raw materials is closely related to the technical reference of the production system. This time, The company does not yet have an official SOP regarding inspection and receipt of materials from suppliers.

\subsection{Proposed improvements}

Proposed improvements for the Company are SOPs for the inspection and receipt of industrial and non-processed industrial materials. In preparing the SOP, three stages must be done. Three steps in compiling SOPs according to Ekotama [23], there are : (1) Determine the type of work and workflow, (2) Describe in the form of work charts, and (3) Write in the form of descriptions. The proposed SOP for inspection and receipt of industrially processed materials can be seen in Table 6. The proposed SOP for check and receipt of industrial non-processed materials can be seen in Table 7.

Please cite this article as: Suhardi, B., Putri, N., \& Astuti, R. (2019). Implementation of CPPB-IRT, WISE, and Halal Guarantee System on Bread Production. Jurnal Teknik Industri, 20(1), 22-33. 
Table 6. SOP Examination and Acceptance of Industrial Processed Materials

\begin{tabular}{cll} 
Company Logo & Document No & $: 001$ \\
Company & Date & $: 26$ September 2018 \\
\hline Operating Procedure for & Revision & $: 1$ \\
\cline { 2 - 2 } Acceptance of Industrial & Revision Date & $: 10$ September 2018 \\
\cline { 2 - 3 } Page & $: 1$ from 2 \\
\hline
\end{tabular}

\section{Purpose}

To determine the suitability of materials received by the Company from suppliers in accordance with the standards set by the Company

2. Tools and Materials

a. Purchase Order

b. Records of raw material purchases

3. Related Parties

a. The person in charge of inspection of raw materials

b. The person in charge of the warehouse

c. Workers

4. Procedure

a. The person in charge of raw material inspection checks the purchase order.

b. The person in charge of inspection of raw materials checks the name of the material, the condition of the packaging, the MUI Halal logo, the expiration date, the quality, and the quantity of the product. If the raw material received is not suitable, then immediately contact the supplier to return the raw material.

c. Workers move the appropriate material to the warehouse based on wet and dry material.

d. The person in charge of the warehouse ensures that the material is stored in the warehouse safely, well and cleanly

e. The person in charge records incoming items and materials out on the stock card

Table 7. SOP for Inspection and Receipt of Non-Processed Industrial Materials

\begin{tabular}{cll}
\hline \multicolumn{1}{c}{ Company Logo } & Document No & $: 002$ \\
\hline \multicolumn{1}{c}{ Company } & Date & $: 26$ September 2018 \\
\hline Standard Operating Procedure for & Revision & $: 1$ \\
\cline { 2 - 3 } Inspecting and Receiving Industrial Non- & Revision Date & $:$ 10 September 2018 \\
\cline { 2 - 3 } Processed Raw Materials & Page & $: 2$ from 2 \\
\hline
\end{tabular}

1. Purpose

To determine the suitability of Non-Processed Industrial Materials received by the Company

from suppliers by the standards set by the Company

2. Tools and Materials

a. Purchase Order Non-Processed Industrial Materials

b. Records of Non-Processed Industrial Materials purchases

3. Related Parties

a. The person in charge of inspection of Non-Processed Industrial Materials

b. The person in charge of the warehouse

c. Workers

4. Procedure

a. The person in charge of Non-Processed Industrial Materials inspection checks the purchase order.

b. The person in charge of inspection of Non-Processed Industrial Materials checks the name of the material, the condition of the packaging, the MUI Halal logo, the expiration date, the quality, and the quantity of the product. If the raw material received is not suitable, then immediately contact the supplier to return the raw material.

c. Workers move the appropriate material to the warehouse based on wet and dry material.

d. The person in charge of the warehouse ensures that the material is stored in the warehouse safely, well and cleanly

e. The person in charge records incoming items and materials out on the stock card 


\section{Conclusion}

The results of the identification using the CPPB, WISE and HGS checklists found some discrepancies. Based on the CPPB checklist found six elements that have not been fulfilled. Based on the WISE list, nine elements have not been met. Based on HGS, eight elements have not been met. Proposed improvements are made by making SOPs for inspection and receipt of materials. SOP for control and receipt of materials for industrial and non-processed industrial processes. For the next research is to make a new measuring instrument to assess food safety standards (CPPB), WISE, and HGS at the same time. The three checklists (CPPB, WISE, and HGS) have several standard criteria.

\section{References}

[1] "Kota Surakarta Dalam Angka 2018," ed. Surakarta: BPS Kota Surakarta, 2018. https://surakartakota.bps.go.id/

[2] A. C. Sonaru, A. Rahman, and C. F. Mada Tantrika, "Analisa Ketidaksesuaian Persyaratan Cara Produksi Pangan Yang Baik Untuk Industri Rumah Tangga (Cppb-irt) Untuk Meminimasi Kontaminasi Produk Roti (Studi Kasus: Perusahaan X)," Jurnal Rekayasa dan Manajemen Sistem Industri, vol. 2, pp. p382-395, 2014. http://jrmsi.studentjournal.ub.ac.id/index.php/jrmsi/article/view/91

[3] N. Wijayant and R. A. Laeliocattleya, "Peningkatan Efisiensi Produksi Jenang Dan Kue Kacang Di Koperasi Wanita" Mitra Wanita" Di Kecamatan Kanigoro, Kabupaten Blitar," Teknologi Pangan: Media Informasi dan Komunikasi Ilmiah Teknologi Pertanian, vol. 8, 2017. http://jurnal.yudharta.ac.id/v2/index.php/ Teknologi-Pangan/article/view/910

[4] A. Herlambang, E. Asmawati, and Y. Haryono, "Implementasi Cara Produksi Pangan yang Baik untuk Industri Rumah Tangga Kerupuk di Sidoarjo," Agro Kreatif, vol. 4, pp. 31-37, 2018. http://repository.ubaya.ac.id/id/eprint/34148

[5] Y. Yunita, "Studi Penerapan Cara Produksi Makanan yang Baik pada Jajanan Bakso yang Dikonsumsi Murid di Sdn Kompleks Mangkura Kota Makassar," Media Kesehatan Masyarakat Indonesia, vol. 9, pp. 153-161, 2016. http://dx.doi.org/10.30597/mkmi.v9i3.459

[6] I. S. Komala, L. Widajanti, and D. R. Pangestuti, "Cara Produksi Pangan Yang Baik Untuk Industri Rumah Tangga (Cppb-Irt) Perusahaan Tahu Putih "Sl" Kabupaten Semarang Tahun 2017," Jurnal Kesehatan Masyarakat (e-Journal), vol. 5, pp. 690-697, 2017. https://ejournal3.undip.ac.id/index.php/jkm/article/ view/18750

[7] R. Yudhastuti, "Penerapan Good Manufactoring Practices Pada Industri Rumah Tangga Kerupuk Teripang di Sukolilo Surabaya," Jurnal Kesehatan Lingkungan, vol. 7, pp. 148-158, 2014. http://repository.unair.ac.id/id/eprint/41179

[8] A. L. Made, "Penerapan Metode Hazard Identification and Risk Assessment untuk Identifikasi Potensi Bahaya di IKM Tahu Sari Murni Mojosongo," Universitas Sebelas Maret, 2018. https://eprints.uns.ac.id/id/eprint/39933

[9] B. Suhardi, P. W. Laksono, J. M. Rohani, and T. S. Ching, "Analysis of the Potential Hazard Identification and Risk Assessment (HIRA) and Hazard Operability Study (HAZOP): Case Study," International Journal of Engineering \& Technology, vol. 7, pp. 1-7, 2018.

[10] Rajagopal, "Determinants of shopping behavior of urban consumers," Journal of International Consumer Marketing, vol. 23, pp. 83-104, 2011.

https://doi.org/10.1080/08961530.2011.543051

Please cite this article as: Suhardi, B., Putri, N., \& Astuti, R. (2019). Implementation of CPPB-IRT, WISE, and Halal Guarantee System on Bread Production. Jurnal Teknik Industri, 20(1), 22-33. 
[11] M. Manzouri, M. Nizam Ab Rahman, N. Saibani, and C. Rosmawati Che Mohd Zain, "Lean supply chain practices in the Halal food," International Journal of Lean Six Sigma, vol. 4, pp. 389-408, 2013. https://doi.org/10.1108/IJLSS-10-2012-0011

[12] S. Prabowo and A. A. Rahman, "Sertifikasi halal sektor industri pengolahan hasil pertanian," in Forum penelitian Agro Ekonomi, 2016, pp. 57-70. http://dx.doi.org/10.21082/fae.v34n1.2016.57-70

[13] S. Chairunnisyah, "Peran Majelis Ulama Indonesia Dalam Menerbitkan Sertifikat Halal Pada Produk Makanan Dan Kosmetika," EduTech: Jurnal Ilmu Pendidikan dan Ilmu Sosial, vol. 3, 2017.

[14] A. Rahayu, H. M. Kholik, and D. P. Restuputri, "Upaya Pengurangan Human Error Pada Kecelakaan Kerja Dengan Metode Sherpa Dan Jsa Di Perum Perhutani KBM-Industri Kayu Gresik," Jurnal Teknik Industri, vol. 16, pp. 53-62, 2015. https://doi.org/10.22219/JTIUMM.Vol16.No2.53-62

[15] F. Rohmawan and D. P. Restuputri, "Penggunaan Metode Heart Dan JSA Sebagai Upaya Pengurangan Human Error Pada Kecelakaan Kerja Di Departemen Produksi," Jurnal Teknik Industri, vol. 17, pp. 1-11, 2016. https://doi.org/10.22219/JTIUMM.Vol17.No1.1-11

[16] B. Suhardi, M. Kadita, and P. W. Laksono, "Perbaikan Proses Produksi Dengan Standar Cara Produksi Pangan yang Baik (CPPB) dan Work Improvement in Small Enterprise (Wise) Pada Industri Kerupuk Sala," Simetris: Jurnal Teknik Mesin, Elektro dan Ilmu Komputer, vol. 9, pp. 579-586, 2018. https://doi.org/10.24176/simet.v9i1.2020

[17] C. Backhouse and N. Mohamad, "A framework for the development of Halal food products in Malaysia," 2014. https://dspace.lboro.ac.uk/2134/14584

[18] T. N. Ma'rifat and M. Sari, "Penerapan Sistem Jaminan Halal Pada UKM Bidang Olahan Pangan Hewani," Khadimul Ummah, vol. 1, 2017.

[19] R. A. I. Putri, Y. Rohayati, and A. N. Aisha, "Evaluasi Pemenuhan Kriteria CPPBIRT dan Sertifikasi Halal Pada UKM Pelangi Rasa," JRSI (Jurnal Rekayasa Sistem dan Industri), vol. 2, pp. 17-24, 2015. https://doi.org/10.25124/jrsi.v2i03.60

[20] D. A. Septina, Y. Rohayati, and A. N. Aisha, "Perbaikan Proses Bisnis Ukm Kerupuk Kentang Ibu Risty Untuk Pemenuhan Kriteria Cppb-irt Dan Sertifikasi Halal Menggunakan Metode Bpi," eProceedings of Engineering, vol. 2, 2015. https://libraryeproceeding.telkomuniversity.ac.id/index.php/engineering/article/vi ew/1463

[21] D. R. Damarasri, "Penerapan Good Manufacturing Practice dan Work Improvement in Small Enterprise pada Usaha Kecil dan Menengah untuk Pemenuhan Standar Kesehatan (Studi Kasus: UKM Tempe Tenggilis Mejoyo Surabaya)," Institut Teknologi Sepuluh Nopember, Surabaya, 2013.

[22] C.-C. Hsu and B. A. Sandford, "The Delphi technique: making sense of consensus," Practical assessment, research \& evaluation, vol. 12, pp. 1-8, 2007.

[23] S. Ekotama, "Pedoman Mudah Menyusun SOP," Media Pressindo, Yogyakarta, 2015 . 